\title{
Pazopanib and sunitinib trigger autophagic and non-autophagic death of bladder tumour cells
}

\author{
M Santoni ${ }^{1,6}$, C Amantini ${ }^{2,6}, \mathrm{M} \mathrm{B}$ Morelli $^{2}, \mathrm{~S}$ Liberati $^{2,3}$, V Farfariello $^{2,4}, \mathrm{M} \mathrm{Nabissi}^{2}, \mathrm{~L} \mathrm{Bonfili}^{5}, \mathrm{~A} \mathrm{M} \mathrm{Eleuteri}^{5}$, \\ M Mozzicafreddo ${ }^{5}$, L Burattini ${ }^{1}$, R Berardi $^{1}$, S Cascinu ${ }^{1}$ and G Santoni ${ }^{\star}, 2$ \\ ${ }^{1}$ Department of Medical Oncology, Polytechnic University of the Marche Region, 60121 Ancona, Italy; ${ }^{2}$ School of Pharmacy, \\ Experimental Medicine Section, University of Camerino, 62032 Camerino, Italy; ${ }^{3}$ Department of Molecular Medicine, \\ Sapienza University, 00161 Rome, Italy; ${ }^{4}$ Department of Urology and Andrology, University of Perugia, 06100 Perugia, Italy and \\ ${ }^{5}$ School of Biosciences and Biotechnology, University of Camerino, 62032 Camerino, Italy
}

Background: Tyrosine kinase inhibitors (TKI) such as sunitinib and pazopanib display their efficacy in a variety of solid tumours. However, their use in therapy is limited by the lack of evidence about the ability to induce cell death in cancer cells. Our aim was to evaluate cytotoxic effects induced by sunitinib and pazopanib in 5637 and J82 bladder cancer cell lines.

Methods: Cell viability was tested by MTT assay. Autophagy was evaluated by western blot using anti-LC3 and anti-p62 antibodies, acridine orange staining and FACS analysis. Oxygen radical generation and necrosis were determined by FACS analysis using DCFDA and PI staining. Cathepsin B activation was evaluated by western blot and fluorogenic Z-Arg-Arg-AMC peptide. Finally, gene expression was performed using RT-PCR Profiler array.

Results: We found that sunitinib treatment for $24 \mathrm{~h}$ triggers incomplete autophagy, impairs cathepsin B activation and stimulates a lysosomal-dependent necrosis. By contrast, treatment for $48 \mathrm{~h}$ with pazopanib induces cathepsin B activation and autophagic cell death, markedly reversed by CA074-Me and 3-MA, cathepsin B and autophagic inhibitors, respectively. Finally, pazopanib upregulates the $\alpha$-glucosidase and downregulates the TP73 mRNA expression.

Conclusion: Our results showing distinct cell death mechanisms activated by different TKls, provide the biological basis for novel molecularly targeted approaches.

In recent years, a better understanding of the role of vascular endothelial growth factor (VEGF) and mammalian target of rapamycin pathways has led to the addition of several agents to the therapeutic landscape of a wide number of tumour types. Among these antiangiogenic agents, sunitinib has been approved for the treatment of metastatic renal carcinoma (mRCC) (Motzer et al, 2007) and gastro-intestinal stromal tumour (Demetri et al, 2006) and pazopanib for mRCC (Sternberg et al, 2010) and soft tissue sarcoma (van der Graaf et al, 2012). Sunitinib is a tyrosine kinase inhibitor (TKI) that targets VEGF receptor-1, -2, -3
(VEGFR-1,-2,-3), platelet-derived growth factor receptor (PDGFR) $\alpha / \beta$, tyrosine protein kinase Kit (c-Kit), fms-related tyrosine kinase 3 and rearranged during transfection (O'Farrell et al, 2003; Schueneman et al, 2003; Faivre et al, 2007). Pazopanib is an oral TKI that targets VEGFR-1,-2-3, PDGFR $\alpha$ and $\beta$, fibroblast growth factor receptor-1, -3 (FGFR-1,-3), IL-2-inducible T-cell kinase, lymphocyte-specific protein tyrosine kinase, macrophage colony stimulating factor 1 receptor (c-Fms) and c-Kit.

Sunitinib, but not pazopanib, functions as a lysosomotrophic agent predominantly sequestered in the lysosome compartments

${ }^{\star}$ Correspondence: Professor G Santoni; E-mail: giorgio.santoni@unicam.it

${ }^{6}$ These authors contributed equally to this work.

Received 3 April 2013; revised 18 June 2013; accepted 3 July 2013; published online 25 July 2013

(c) 2013 Cancer Research UK. All rights reserved 0007-0920/13 
(Gontik et al, 2011). Lysosomotropic agents accumulate in lysosomes because they become ionised inside acidic environments. At physiological $\mathrm{pH}$, these compounds are non-ionised and passively diffuse across the lipid bilayers of cellular organelles. Thus, elevated concentrations of these compounds within the lysosomes, much higher than those found in the cytoplasm (Kaufmann and Krise, 2007), cause structural and functional alterations, such as an increase of lysosomal $\mathrm{pH}$, vast expansion in lysosome volume, phospholipidosis and inhibition of lysosomal (cathepsins) enzymatic activity (Nadanaciva et al, 2011; Funk and Krise, 2012).

Although transitional cell carcinoma (TCC) of the bladder is one of the most common malignancies of the genitourinary tract (Jemal et al, 2010), the development of antiangiogenic agents effective in this disease is still in a very preliminary phase of clinical research. Bladder cancer (BC) is strongly associated with aberrations of various molecular pathways involved in cellular proliferation, tumour angiogenesis and apoptosis. Various tyrosine kinase receptors such as epidermal growth factor receptor, PDGFR, insulin-like growth factor I receptor, VEGFR, FGFR and hepatocyte growth factor receptor have been shown to be overexpressed in BCs. Sunitinib has been found to be active against urothelial carcinoma (UC) both in vivo and in vitro and to enhance cisplatin activity (Sonpavde et al, 2009). In vitro, the antiproliferative effects of sunitinib in KK47, KK47/DDP20 (cysplatin resistant) and KK47/ADR (adriamycin resistant) BC cell lines is due to the suppression of extracellular-regulated kinase 1/2 (ERK1/2) phosphorylation (Takeuchi et al, 2012). Moreover, sunitinib exerts a potent antitumour effect in human UC cells by suppressing protein kinase B (AKT) pathway and promoting Bad/Bax-mediated apoptosis and by enhancing the antitumour effects of gemcitabine (Yoon et al, 2011). In addition, the combination of sunitinib with epirubicin showed a synergistic cytotoxic effect and has been shown to inhibit cell migration, arrest cell cycle at G2/M phase, with an increase of subG1 fraction in mouse bladder tumour MBT-2 cells (Wu et al, 2012), and prolong the survival in a preclinical orthotopic model (Chan et al, 2012). Finally, it was used in a phase II study in patients with metastatic UC, and although it did not achieve the threshold of response, objective anti-tumour responses were observed (Gallagher et al, 2010). As regards pazopanib, it shows modest activity as single agent; however, it has been found to synergise with docetaxel in docetaxel-resistant BC cells. These effects were associated with decrease of phospho-AKT levels (Li et al, 2011). Moreover, a role as single agent in patients with metastatic UC has been recently reported (Necchi et al, 2012).

The aim of our study was to evaluate the different mechanisms responsible for the cytotoxic effects induced in vitro by sunitinib and pazopanib in $\mathrm{BC}$ cells.

\section{MATERIALS AND METHODS}

Cell lines. The p53 mutant, 5637 and J82 squamous and urothelial BC cell lines, purchased from American Type Culture Collection (ATCC, Rockville, MD, USA), were maintained in RPMI-1640 medium (Lonza Bioresearch, Basel, Switzerland) supplemented with $10 \%$ heat-inactivated fetal bovine serum, $2.5 \mathrm{~mm}$ $\mathrm{N}$-2-hydroxyethylpiperazine-N'-2-ethanesulfonicacid (HEPES), $2 \mathrm{mM} \mathrm{L}$-glutamine, $100 \mathrm{IU} \mathrm{ml}^{-1}$ of penicillin and $100 \mathrm{~g} \mathrm{ml}^{-1}$ of streptomycin (Lonza) at $37^{\circ} \mathrm{C}, 5 \% \mathrm{CO}_{2}$ and $95 \%$ humidity.

Reagents. Sunitinib and pazopanib from Pfizer (New York, NY, USA) and Glaxo Group Limited (Greenford, UK), respectively, were dissolved in dimethyl sulfoxide (DMSO). The following rabbit polyclonal antibodies (Abs) were used: anti-p62 (1:1000, Cell Signaling Technology, Denver, CO, USA), anti-microtubule-associated protein-1 light chain 3 (LC3, $2 \mu \mathrm{g} \mathrm{ml}^{-1}$, Novus Biologicals, Littleton, CO, USA), anti-ERK (1:1000, Cell Signaling), and anti-cathepsin B (anti-CB, 1:1000, Santa Cruz Biotechnology, Santa Cruz, CA, USA). The following mouse monoclonal Abs were used: anti-phospho ERK (anti-pERK, 1:2000, Cell Signaling) and horseradish peroxidase (HRP)-conjugated anti-glyceraldehyde-3-phosphate dehydrogenase (anti-GAPDH, 1:5000, Sigma-Aldrich, St Louis, MO, USA). HRP-conjugated donkey anti-rabbit $(1: 20000)$ and HRP-conjugated sheep anti-mouse $(1: 2000)$ were from GE Healthcare Bio-Sciences AB (Uppsala, Sweden). Annexin-V-FITC was from Enzo Life Sciences Inc. (Farmingdale, NY, USA). Acridine orange (AO, $1 \mu \mathrm{g} \mathrm{ml}^{-1}$ ), Lysotracker red (50 nM) and 5,5',6,6'-tetrachloro-1, $1^{\prime} .3 .3^{\prime}$-tetraethylbenzimidazolcarbocyanine iodide (JC-1, $10 \mu \mathrm{g} \mathrm{ml}^{-1}$ ) were from Invitrogen (San Diego, CA, USA). 2', $7^{\prime}$-Dichlorofluorescein diacetate (DCFDA, $10 \mu \mathrm{g} \mathrm{ml}^{-1}$ ), dimethyl sulfoxide (DMSO, used as vehicle), propidium iodide (PI) $1 \mu \mathrm{g} \mathrm{ml}^{-1}, 3$-(4,5-dimethylthiazol2-yl)-2,5-diphenyltetrazolium bromide (MTT) and chloroquine (CQ, $100 \mu \mathrm{M})$ were from Sigma-Aldrich. Bafilomycin A (50 nM) and 3-MA $(2.5 \mathrm{~mm})$ were from Labogen (Milan, Italy). Ca074Me $(2.5$ and $10 \mu \mathrm{M})$ was from Vinci-Biochem (Florence, Italy). The MEK inhibitor PD98059 $(50 \mu \mathrm{M})$ was from Tocris Bioscience (Bristol, UK).

MTT assay. 5637 and J82 BC cell lines $\left(3 \times 10^{5}\right.$ per ml) were seeded into 96-well plates and cultured with different doses of sunitinib, pazopanib $(5,10,15,20 \mu \mathrm{M})$ or respective vehicle at different times at $37^{\circ} \mathrm{C}, 5 \% \mathrm{CO}_{2}$. At the end of the treatment, $0.8 \mathrm{mg} \mathrm{ml}^{-1}$ of MTT was added to the samples and incubated for $3 \mathrm{~h}$. After the removal of medium from the wells, the formazan crystals were dissolved with 100 ul per well of DMSO and the coloured solutions were read by microtiter plate spectrophometer (BioTek Instruments, Winooski, VT, USA). In some experiments, cells were pre-treated with $3-\mathrm{MA}(2.5 \mathrm{~mm})$ or with CA074Me $(2.5 \mu \mathrm{M})$ for $1 \mathrm{~h}$ before the addition of pazopanib $(20 \mu \mathrm{M})$ and with bafilomycin A1 $(50 \mathrm{nM})$ or chloroquine $(100 \mu \mathrm{M})$ before the addition of sunitinib $(20 \mu \mathrm{M})$. Four replicates were used for each treatment, and data were represented as the average of at least three separate experiments.

Detection of acidic vesicular organelles (AVOs). $\mathrm{AO}$ is a fluorescent molecule used either to identify apoptotic cell death or autophagy. It can interact with DNA emitting green fluorescence or accumulate in acidic organelles in which it becomes protonated forming aggregates that emit bright red fluorescence. Briefly, 5637 and J82 BC cell lines $\left(4 \times 10^{5}\right.$ per ml) were seeded into 24 -well plates and cultured at different times with pazopanib, sunitinib $(20 \mu \mathrm{M})$ or vehicle. Cells were then washed, stained with $\mathrm{AO}$ and the percentage of bright red fluorescence (FL3)-positive cells was determined over 10000 events and analysed on a FACScan cytofluorimeter using the CellQuest software (Becton Dickinson, San Josè, CA, USA).

Cell death analysis. Apoptosis of 5637 and J82 cells was evaluated using FITC-conjugated Annexin-V (Ann-V) and PI staining followed by biparametric FACS analysis. Briefly, cells were treated for $24 \mathrm{~h}$ with $(20 \mu \mathrm{M})$ sunitinib or vehicle and then incubated with Ann-V and PI according to the manufacturer's instruction. For autophagic cell death, 5637 and J82 cells were treated for $48 \mathrm{~h}$ with pazopanib $(20 \mu \mathrm{M})$ or vehicle and incubated for $20 \mathrm{~min}$ with PI. In some experiments, cells were pre-treated with 3-MA (2.5 mM) for $1 \mathrm{~h}$ before the addition of pazopanib. Also, PI staining was performed in 5637 and J82 cells treated with vehicle, $20 \mu \mathrm{M}$ sunitinib or pre-treated with $50 \mathrm{~nm}$ bafilomycin A for $1 \mathrm{~h}$ before the addition of sunitinib. The percentage of positive cells determined over 10000 events was analysed on a FACScan cytofluorimeter using the CellQuest software. 
Lysosome staining by Lysotracker. To investigate the involvement of lysosomes, BC cells were stained with Lysotracker-red. Briefly, 5637 and J82 cells $\left(1 \times 10^{5}\right.$ per $\left.\mathrm{ml}\right)$, seeded into six-well plates, were treated with sunitinib $(20 \mu \mathrm{M})$ or vehicle for $24 \mathrm{~h}$. Supernatants were then replaced with $1 \mathrm{ml}$ per well of Lysotracker-red probe ( $50 \mathrm{~nm}$ in medium) for $1 \mathrm{~h}$ at $37^{\circ} \mathrm{C}$. Green fluorescence (sunitinib) and red fluorescence (Lysotracker) were detected by analysing random fields at $\times 40$ magnification using a BX51 fluorescence microscope (Olympus, Milan, Italy). Merge images were obtained by using the DP controller software (Olympus).

Reactive oxygen species (ROS) production. 5637 and J82 cells $\left(4 \times 10^{5}\right.$ per $\left.\mathrm{ml}\right)$ were seeded into 24 -well plates and cultured at different times with sunitinib $(20 \mu \mathrm{M})$ or vehicle. Cells were washed with phosphate-buffered saline, pulsed with DCFDA for $10 \mathrm{~min}$ at $37^{\circ} \mathrm{C}, 5 \% \mathrm{CO}_{2}$ and analysed by FACScan cytofluorimeter using the CellQuest software; fluorescence intensity was expressed in arbitrary units on logarithmic scale.

Mitochondrial transmembrane potential $(\Delta \Psi \mathrm{m})$. Mitochondrial transmembrane potential was evaluated by JC-I staining. 5637 and J82 cells $\left(4 \times 10^{5}\right.$ per $\left.\mathrm{ml}\right)$, seeded into 24 -well plates, were treated with $20 \mu \mathrm{m}$ sunitinib or vehicle at different times and incubated for $10 \mathrm{~min}$ at room temperature with JC-1 dye. Carbonyl cyanide chlorophenylhydrazone protonophore, a mitochondrial uncoupler that collapses $\Delta \Psi \mathrm{m}$, was used as positive control (data not shown). Samples were analysed by a FACScan cytofluorimeter using the CellQuest software; fluorescence intensity was expressed in arbitrary units on logarithmic scale.

CB activity. CB proteolytic activity was measured at $12 \mathrm{~h}$ after sunitinib treatment by using the fluorogenic peptide Z-Arg-Arg-AMC at a final concentration of $50 \mu \mathrm{M}$ (Tchoupe et al, 1991). The mixture, containing $5 \mu \mathrm{g}$ of protein lysate, was incubated in $50 \mathrm{~mm}$ phosphate buffer $\mathrm{pH} 6.0,1 \mathrm{~mm}$ EDTA and $2 \mathrm{~mm}$ dithiothreitol for $1 \mathrm{~h}$ at $30^{\circ} \mathrm{C}$. The fluorescence of the hydrolysed 7-amino-4-methyl-coumarin (AMC, $\lambda$ exc $=365 \mathrm{~nm}$, $\lambda$ em $=449 \mathrm{~nm}$ ) was detected on a SpectraMax Gemini XPS microplate reader (Molecular Devices, Sunnyvale, CA, USA). The effective $\mathrm{CB}$ contribution to the proteolysis was evaluated through control experiments performed using the specific inhibitor $(10 \mu \mathrm{M})$ CA074Me (Tchoupe et al, 1991).

Western blot. 5637 and J82 cells, untreated or treated at different times with $(20 \mu \mathrm{M})$ pazopanib, sunitinib or vehicle, were lysed in a lysis-buffer containing protease inhibitor cocktail (Sigma-Aldrich). Lysates were separated on sodium dodecyl sulphate polyacrylamide gel $(9,12$ and 14\%) and transferred. Non-specific binding sites were blocked with $5 \%$ low-fat dry milk in phosphate-buffered saline $0.1 \%$ Tween 20 for $1 \mathrm{~h}$. Blots were incubated with the primary Abs: anti LC3, anti-p62, anti-ERK, anti-phospho ERK, and anti-CB followed by the appropriate HRP-conjugated secondary Abs. In some experiments, bafilomycin A1 (50 nM) or PD98059 $(50 \mu \mathrm{M})$ were added $1 \mathrm{~h}$ before pazopanib treatment. The detection was performed using the LiteAblot PLUS or the LiteAblot TURBO (EuroClone, Milano, Italy) kits, and densitometric analysis was carried out by a Chemidoc using the Quantity One software (Bio-Rad, Hercules, CA, USA). One representative out of three independent experiments is shown. For quantification, GAPDH was used as loading control.

RT-PCR profiler array. Total RNA was extracted from 5637 and J82 cells, treated with $(20 \mu \mathrm{M})$ pazopanib or vehicle, with the RNeasy Mini Kit (Qiagen, Hilden, Germany) and reverse transcribed using the Reaction Ready first strand cDNA kit (Superarray Bioscience Corporation, Frederick, MD, USA).

qRT-PCR was performed using the IQ5 Multicolor Real-time PCR detection system (Bio-Rad), the $\mathrm{RT}^{2}$ real-time SYBR green PCR Mix and the human Autophagy plates (Superarray Bioscience Corporation) according to manufacturer's instructions.

Statistical analysis. The statistical significance was determined by Student's $t$-test and by Anova with Bonferroni's post-test. No statistically significant difference was found between untreated and vehicle (DMSO)-treated 5637 and J82 cells (data not shown).

\section{RESULTS}

Sunitinib and pazopanib inhibit in a dose- and time-dependent manner the growth of $\mathbf{5 6 3 7}$ and J82 cells. The ability of sunitinib and pazopanib to inhibit the growth of 5637 and J82 cells was evaluated by dose-response and time course analyses using the MTT assay. We found that both TKI compounds reduced the growth of BC cells at $\mu \mathrm{M}$ doses. The inhibitory effect of sunitinib on BC cell growth was faster $(24 \mathrm{~h})$ than that induced by pazopanib (48 h) (Supplementary Figure S1). Sunitinib and pazopanib show an $\mathrm{IC}_{50}$ of 16.4 and $15.0 \mu \mathrm{M}$ and 17.3 and $18.4 \mu \mathrm{M}$ in the 5637 and J82 cells, respectively;

Sunitinib and pazopanib trigger the autophagic process in BC cells. Autophagy is a cellular process responsible for the degradation of cytoplasmic components via the lysosomal pathway (Yang and Kliosky, 2010). Although it represents an homeostatic mechanism controlling cell survival, autophagy can also lead to programmed cell death (PCD Type II) (Gozuacik and Kimchi, 2004). In this regard, we evaluated whether treatment of 5637 and J82 cells with $20 \mu \mathrm{m}$ sunitinib and pazopanib at different times stimulates autophagy as indicated by the conversion of LC3-I to LC3-II and p62 protein degradation (Komatsu et al, 2007; Jaakkola and Pursiheimo, 2009; Johansen and Lamark, 2011). We found that sunitinib induces a significant accumulation of lipidated LC3 (LC3-II) and an increase of LC3-II/LC3-I ratio from $6 \mathrm{~h}$ after treatment, which is sustained at $12 \mathrm{~h}$ and slightly declines later in 5637 and J82 cells (Figure 1A). Despite the increase of LC3-II, a marked increase of p62 levels were observed in sunitinib-treated cells (Figure 1B). No p62 degradation was observed at later time points (data not shown). As autophagy requires the formation of autophagosomes, which fuse with endosomes/lysosomes to form AVOs, we evaluated AVO formation by AO staining and FACS analysis. Time course analysis of sunitinib-treated BC cells evidenced a slight increase in J82 cells at $24 \mathrm{~h}$ after treatment, as compared with vehicle-treated cells, whereas no AVO formation was found at any time in 5637 cells (Figure 1C).

Similarly to sunitinib, pazopanib induced accumulation of LC3-II and an increase of LC3-II/LC3-I ratio, although at later time in both BC cells (Figure 2A). In contrast, this increase was accompanied by a progressive degradation of p62 protein from 24 to $72 \mathrm{~h}$ (Figure 2B). In addition, a profound increase in AVO formation from 12 to $72 \mathrm{~h}$ in pazopanib-treated 5637 and J82 cells was detected (Figure 2C). We further addressed the pazopanibinduced autophagic activity as a dynamic process by measuring the autophagic flux. We found that both the LC3-II and p62 protein levels increased after treatment with bafilomycin A1, implying the basal autophagic activity (Figure 3A). Thus, sunitinib triggered 'incomplete autophagy', whereas pazopanib stimulated autophagy in 5637 and J82 cells.

Several reports indicate that autophagy is associated with increased ERK1/2 activation (Rodriguez et al, 2006; Pursiheimo et al, 2009). Thus, we evaluated whether ERK phosphorylation 

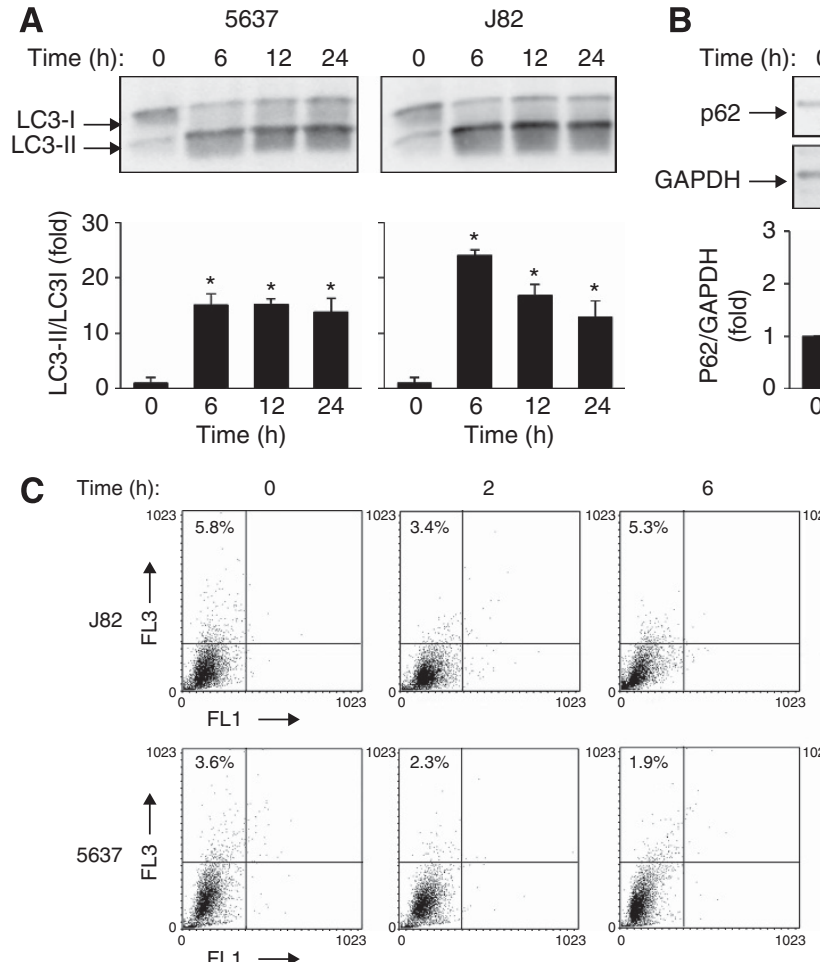

B
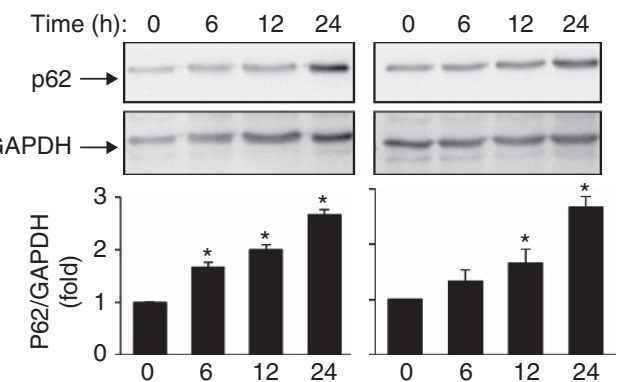

Figure 1. Sunitinib induces incomplete autophagy in BC cells. (A and B) Lysates from 5637 and J82 cell lines, untreated or treated with $20 \mu \mathrm{m}$ sunitinib at different times, were separated on 14\% or 10\% SDS-PAGE and probed with anti-LC3 or anti-p62 and anti-GAPDH Abs, respectively. Statistical analysis of densitometric findings, expressed as the mean \pm s.d. was performed by comparing treated with untreated cells, ${ }^{*} P<0.01$. (C) The percentage of bright red fluorescence (FL3)-positive cells was evaluated by AO staining and FACS analysis in 5637 and J82 cells untreated or $20 \mu \mathrm{m}$ sunitinib treated at different times. Dot plots represent one out of three separate experiments.

A
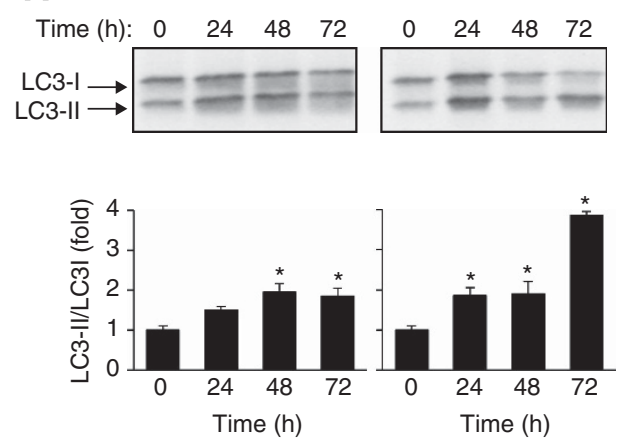

B
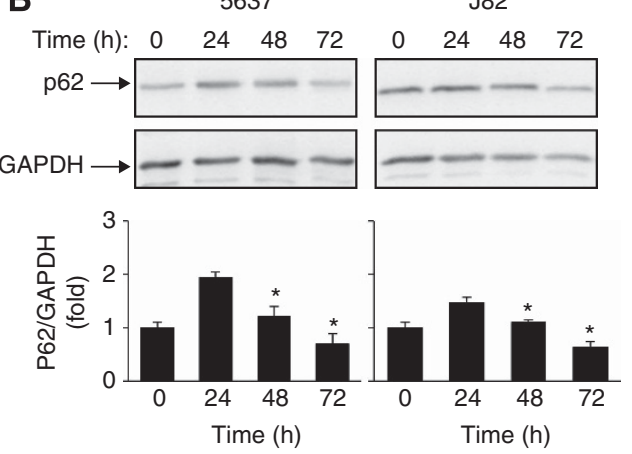

24
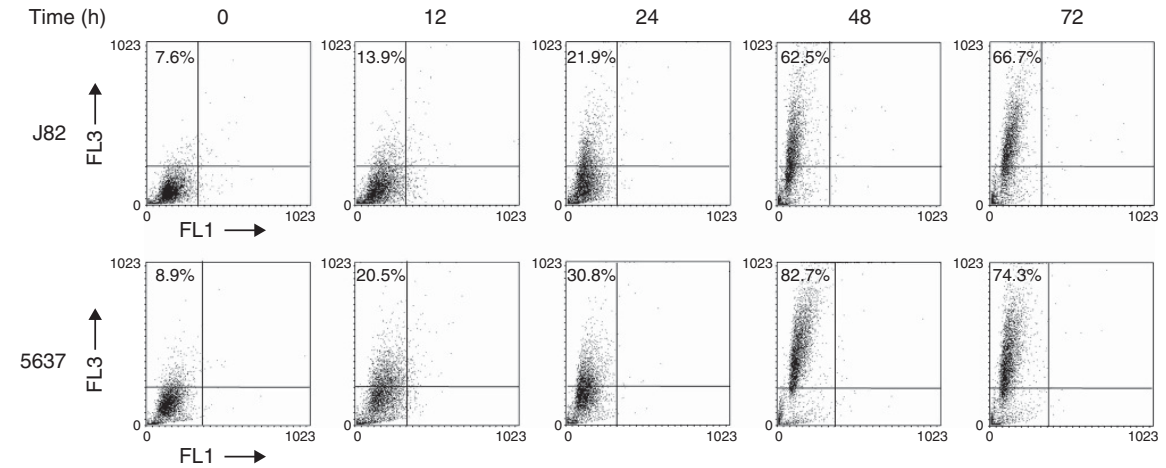

Figure 2. Pazopanib triggers the autophagic process in BC cells. (A and B) Lysates from 5637 and J82 cell lines, untreated or treated with $20 \mu \mathrm{m}$ pazopanib at different times, were separated on 14\% or 10\% SDS-PAGE and probed with anti-LC3 or anti-p62 and anti-GAPDH Abs, respectively. Densitometric analysis, expressed as the mean \pm s.d., was performed by comparing treated with untreated cells, ${ }^{*} P<0.01$.

(C) The percentage of bright red fluorescence (FL3) cells was evaluated by AO staining and FACS analysis in 5637 and J82 cells untreated or $20 \mu \mathrm{M}$ pazopanib treated at different times. Dot plots represent one out of three separate experiments. 
A

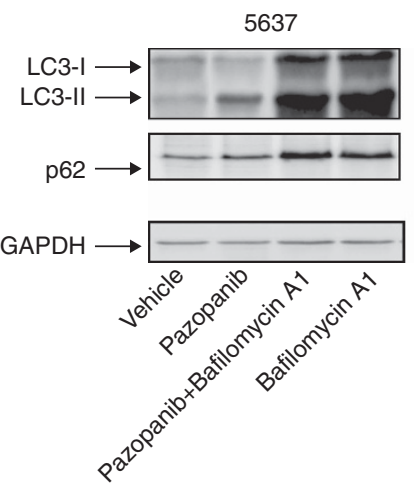

B
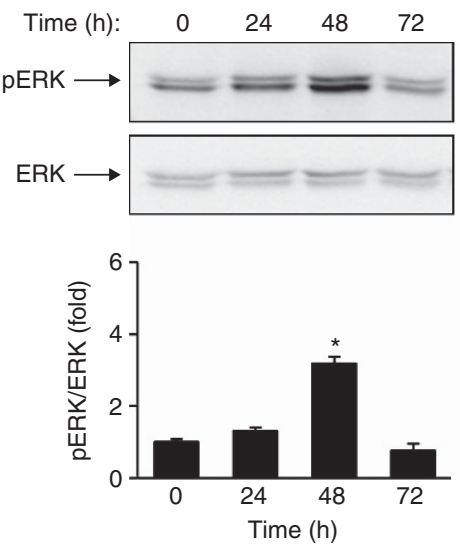

C
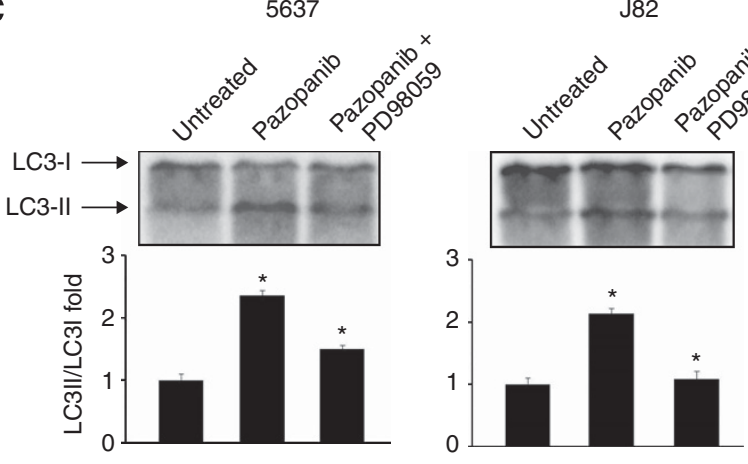

Figure 3. Pazopanib induces autophagic flux and ERK1/2 phosphorylation in BC cells. (A) Lysates from 5637 and J82 cells treated with $20 \mu \mathrm{m}$ pazopanib and $50 \mathrm{~nm}$ bafilomycin A1, alone or in combination, for $48 \mathrm{~h}$ were separated on $14 \%$ or $10 \%$ SDS-PAGE and probed with anti-LC3 or anti-p62 and anti-GAPDH Abs, respectively. (B) Lysates from 5637 and J82 cells untreated or treated with $20 \mu \mathrm{M}$ pazopanib at different times were separated on 12\% SDS-PAGE and probed with anti-pERK or anti-ERK Abs. Densitometric analysis, expressed as the mean \pm s.d., was performed by comparing treated with untreated cells, ${ }^{*} P<0.01$. (C) Lysates from 5637 and J82 cells untreated, treated for $48 \mathrm{~h}$ with $20 \mu \mathrm{m}$ pazopanib or pre-treated for $1 \mathrm{~h}$ with $50 \mu \mathrm{M}$ PD98059 before the addition of pazopanib, were separated on 14\% SDS-PAGE and probed with anti-LC3 Abs. Densitometric analysis, expressed as the mean \pm s.d., was performed by comparing PD9859 + pazopanib- with pazopanib-treated cells and pazopanibtreated with untreated cells, ${ }^{\star} P<0.01$

triggers pazopanib-induced autophagy by using a specific MEK1 inhibitor, PD98059. We found that ERK1/2 is phosphorylated at basal levels; pazopanib strongly increased pERK1/2 phosphorylation in BC cells (Figure 3B) and the PD98059 inhibitor markedly reduced LC3-II formation (Figure 3C). Moreover, the inhibition of pazopanib-induced autophagy by 3-MA does not affect ERK1/2 phosphorylation levels (data not shown). Overall these results suggest that ERK1/2 activation stimulates pazopanibmediated autophagy.

Sunitinib induces lysosomal-dependent necrosis in BC cells. Inhibition of autophagy has been found to stimulate lysosomal cell death signals (Kroemer and Jäättelä, 2005). To evaluate the ability of sunitinib to trigger necrosis or apoptosis of $\mathrm{BC}$ cells, the percentage of $\mathrm{PI}^{+}$and Ann-V ${ }^{+}$cells was evaluated by Ann-V/PI staining and FACS analysis. We found that sunitinib at $24 \mathrm{~h}$ induces necrosis of BC cells (percentage of $\mathrm{PI}^{+} 5637: 86.3 \%$ and J82: 87.3\%), (Figure 4A). Lysosomes are important players in triggering different forms of cell death (Ferri and Kroemer, 2001). Thus, the involvement of lysosome in sunitinib-induced necrosis was evaluated by using the specific lysosome inhibitor, bafilomycin A1 (50 nM), a specific inhibitor of vacuolar type $\mathrm{H}^{+}$-ATPase which abolishes the lysosome acidification and CQ $(100 \mu \mathrm{M})$ that raise the intralysosomal $\mathrm{pH}$ and impairs the autophagic protein degradation (Yoshimori et al, 1991). We found that bafilomycin A1 and CQ (Figures $4 \mathrm{~B}$ and $\mathrm{C}$ ) were able to completely revert the inhibition of growth and the necrosis induced by sunitinib. As sunitinib shows autofluorescence properties, we evaluated by fluorescence microscopy its ability to accumulate in 5637 and J82 cells treated for $24 \mathrm{~h}$. We observed that sunitinib displays a green fluorescence not diffused in the cytoplasm but specifically localised in subcellular compartments (Figure 5A). In addition, in order to confirm that sunitinib functions as lysosomotrophic agent (Gotink et al, 2011), BC cells were treated with sunitinib and stained with Lysotracker red, a specific lysosomal marker, and analysed by fluorescence microscopy. By merge analysis, sunitinib and Lysotracker were found to highly colocalise in the majority of cells (yellow, Figure 5A), demonstrating a lysosomal sequestration of sunitinib. In addition, the trapping of sunitinib in lysosomes in BC cells markedly enhanced lysosome number and size, as indicated by the strong increase of Lysotracker red fluorescence in sunitinibtreated cells compared with control cells (Figure 5A). As some lysosomotrophic drugs are efficiently trapped in mitochondria, where they induce mitochondrial depolarisation through ROS generation, we also used JC-1 and DCFDA staining and FACS analysis to investigate whether sunitinib could induce mitochondrial depolarisation and ROS generation. Neither changes in $\Delta \Psi \mathrm{m}$ nor ROS formation were found in sunitinib-treated 5637 and $\mathrm{J} 82$ cells compared with vehicle-treated ones, at any point in the experiments (Supplementary Figures S2 and S3). Sunitinib, by increasing the lysosome $\mathrm{pH}$, impairs the activity of acid hydrolases (cathepsins) and causes cell death (Puissant et al, 2010; Nadanaciva et al, 2011). Activation of CB results from cleavage of pro-peptide from a mature form $(37 \mathrm{kDa})$ to generate the $\mathrm{CB}$ cleaved activated form $(25 \mathrm{kDa})$ (Figure $5 \mathrm{~B})$. In this regard, we evaluated the ability of sunitinib to affect $\mathrm{CB}$ activation and its enzymatic activity (Figure 5C). We found that $\mathrm{CB}$ is basically activated in untreated or vehicle-treated 5637 and J82 cells, and treatment for $12 \mathrm{~h}$ with sunitinib markedly inhibits $\mathrm{CB}$ activation similarly to the $\mathrm{CB}$ inhibitor CA074Me, as evaluated by a significant reduction of p25 fragment generation (Figure 5B) and $\mathrm{CB}$ enzymatic activity (Figure 5C).

Pazopanib induces autophagic cell death in BC cells. Regarding the effects of pazopanib on BC cell viability, we evaluated whether the reduction of $\mathrm{BC}$ cell viability was the result of a pazopanibinduced autophagic cell death. Thus, the percentage of PI-positive cells was evaluated by PI staining and FACS analysis in 5637 and J82 cells treated for $48 \mathrm{~h}$ with $20 \mu \mathrm{M}$ pazopanib. We found that pazopanib induces cell death of BC cells (5637: $\mathrm{PI}=61 \%$; J82: $\mathrm{PI}=48.5 \%$; Figure $6 \mathrm{~A})$, which is reverted by 3 -MA $(2.5 \mathrm{~mm})$, a class III phosphoinositide 3 kinase autophagic inhibitor that 
A
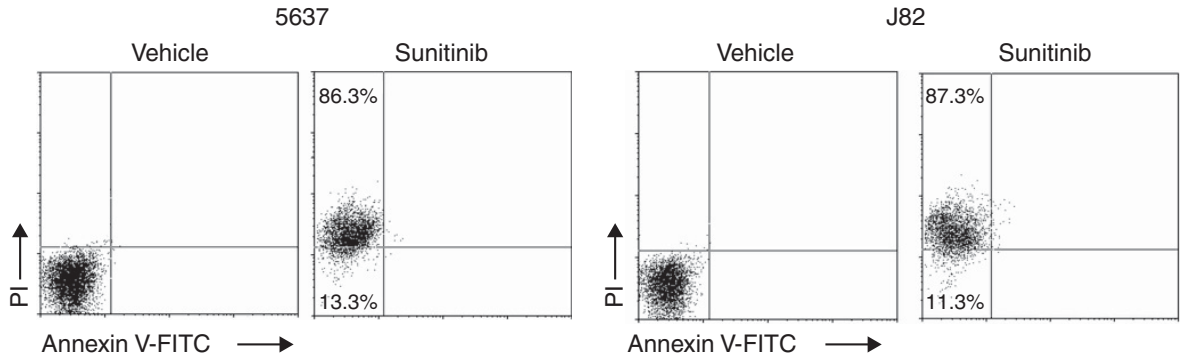

B
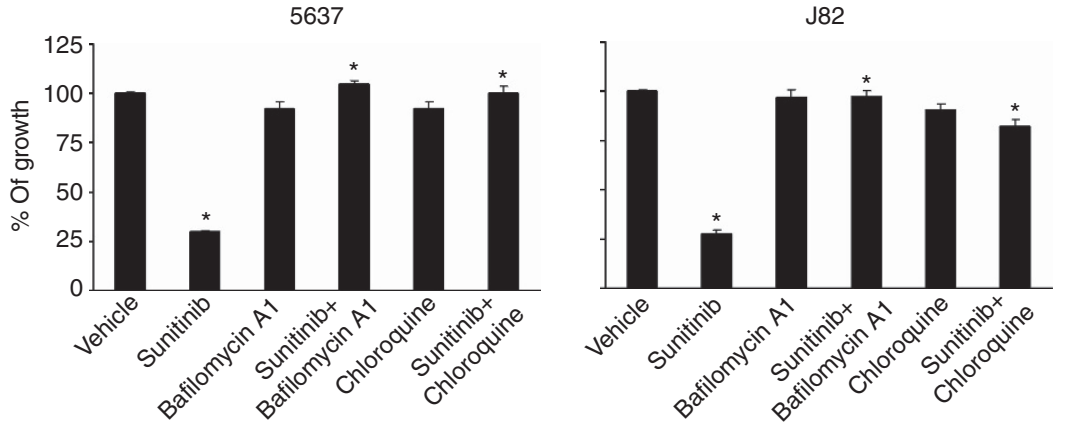

C

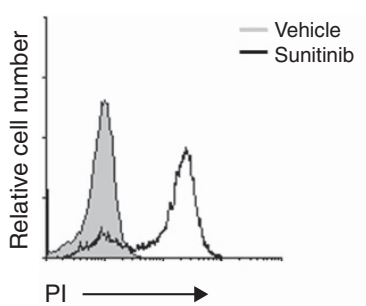

5637

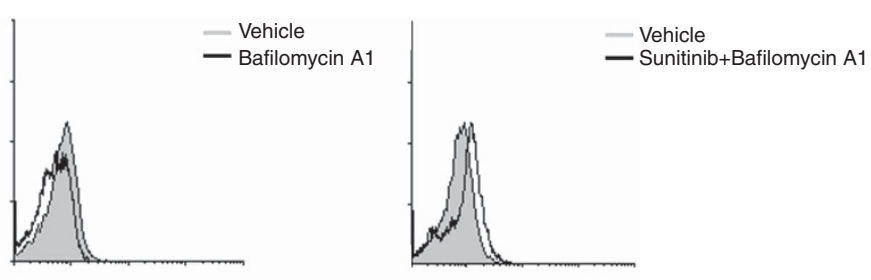

J82
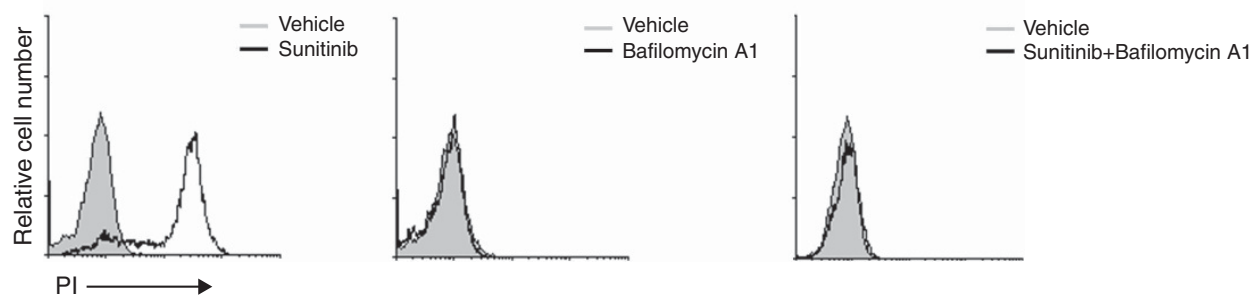

Figure 4. Sunitinib induces lysosomial-dependent necrosis of BC cells. (A) 5637 and J82 cells treated with $20 \mu \mathrm{M}$ sunitinib for $24 \mathrm{~h}$ were stained with Annexin V-FITC and PI and analysed by FACS. Data are expressed as percentage of positive cells and represent one out of three separate experiments. (B) Cell growth of 5637 and J82 cells, treated for $24 \mathrm{~h}$ with vehicle, $20 \mu \mathrm{m}$ sunitinib or pre-treated for $1 \mathrm{~h}$ with $50 \mathrm{~nm}$ bafilomycin A1 or with $100 \mu \mathrm{m}$ chloroquine before the addition of sunitinib, was evaluated by MTT assay at $24 \mathrm{~h}$ after treatment. Data shown are the mean $\pm \mathrm{s}$. d. of three independent experiments. Statistical analysis was performed by comparing sunitinib- with vehicle-treated cells and sunitinib plus bafilomycin A1- with sunitinib-treated cells, ${ }^{*} P<0.01$. (C) Cell viability was assessed in 5637 and $J 82$ cells treated for $24 \mathrm{~h}$ with vehicle, $20 \mu \mathrm{M}$ sunitinib or pre-treated for $1 \mathrm{~h}$ with $50 \mathrm{~nm}$ bafilomycin A1 before the addition of sunitinib by PI staining and FACS analysis. Data are one out of three separate experiments.

regulates the formation of autophagosomes (Mizushima et al, 2010; Figures $6 \mathrm{~B}$ and $\mathrm{C})$.

Pazopanib, by triggering CB activation and activity, induces autophagic cell death in BC cells. No data on the effects of pazopanib in $\mathrm{CB}$ activation and enzymatic activity have been provided so far. Thus, we evaluated the effects of pazopanib on $\mathrm{CB}$ activation and enzymatic activity in BC cells. We found that $20 \mu \mathrm{M}$ pazopanib for $12 \mathrm{~h}$ increases $\mathrm{CB}$ activation, as evaluated by the strong increase of active p25 CB fragment levels in treated cells compared with vehicle-treated cells (Figure 7A), as well as strongly enhanced (2.2-fold) the CB activity (Figure 7B). These effects were completely reverted by the specific $\mathrm{CB}$ inhibitor, $\mathrm{CA} 074 \mathrm{Me}$ $(2.5 \mu \mathrm{M})$ (Figure 7B). Moreover, CA074Me markedly, but not completely, reverted the pazopanib-induced autophagic cell death in BC cells (Figure 7C).

Pazopanib treatment affects autophagic gene expression in $\mathrm{BC}$ cells. To further explore the nature of pazopanib-induced autophagic alteration at gene expression level, we then employed the RT-profiler autophagy PCR array platform that allows quantitative assessment of treatment-induced transcriptional changes of 84 autophagy-related genes (Supplementary Table $\mathrm{S} 1)$. In BC cells, 12 -h treatments with pazopanib significantly altered the expression levels of six and seven genes in J82 and 5637 cells, respectively. Upregulation of ATG9 autophagy-related 9 homolog B (ATG9B), $\alpha$-glucosidase acid (GAA) and cyclindependent kinase inhibitor 1B, p27/Kip1 (CDKN1B) and 


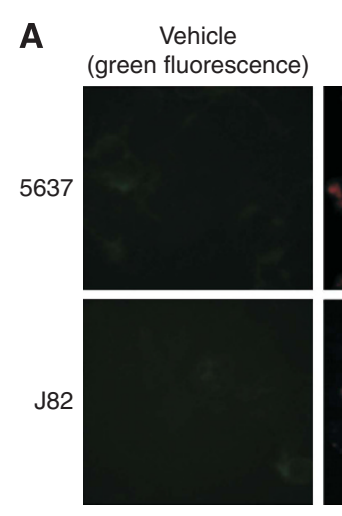

B

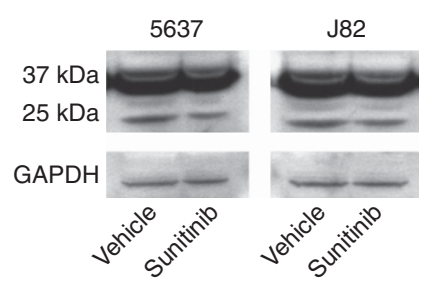

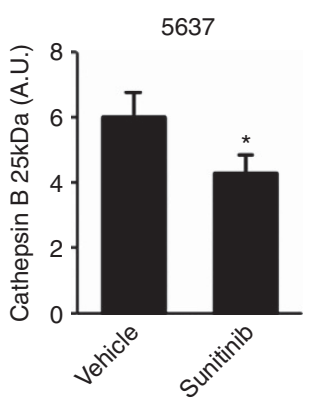
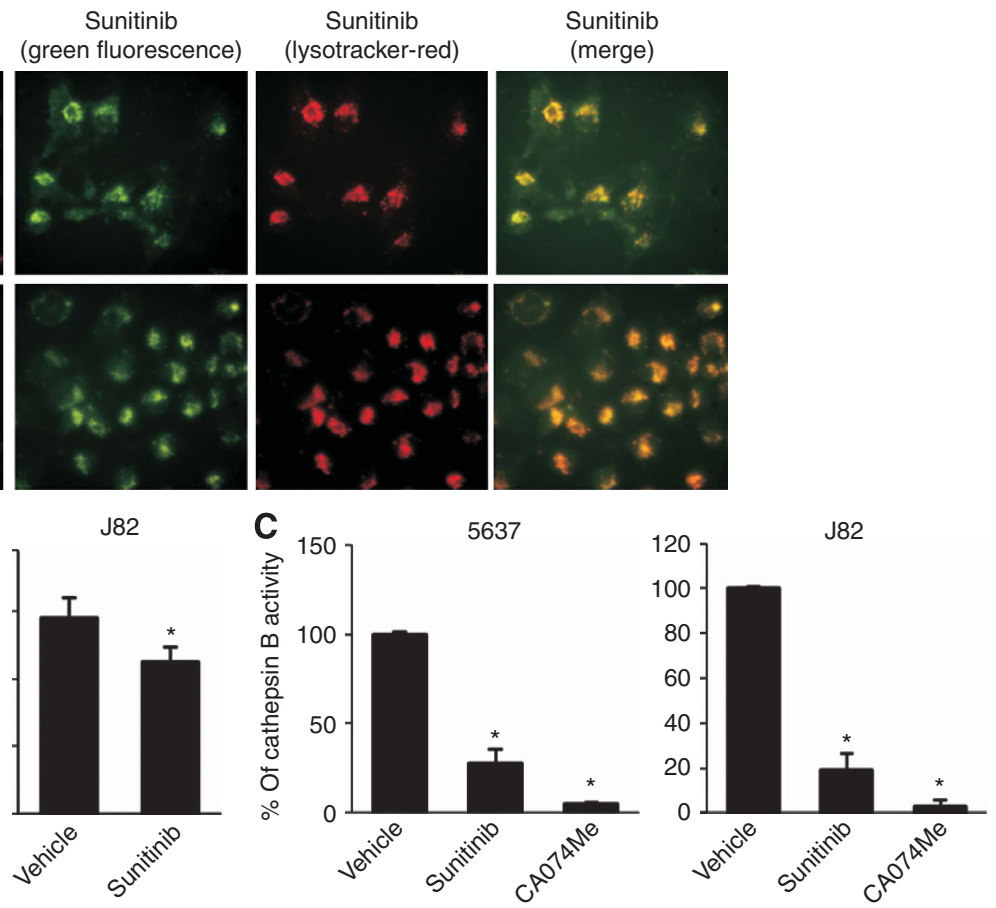

Figure 5. Sunitinib induces lysosome alteration and inhibits CB activity in BC cells. (A) 5637 and J82 cells were treated with $20 \mu \mathrm{M}$ sunitinib or vehicle for $24 \mathrm{~h}$ and stained with Lysotracker red probe. Green and red fluorescence were detected in vehicle- and sunitinib-treated samples by using the BX51 fluorescent microscope. Random fields at $\times 40$ magnification. (B) Lysates from 5637 and J82 cell lines, treated with $20 \mu \mathrm{M}$ sunitinib or vehicle for $12 \mathrm{~h}$, were separated on $10 \%$ SDS-PAGE and probed with anti-CB or anti-GAPDH Abs, respectively. Densitometric analysis, expressed as the mean \pm s.d., was performed by comparing sunitinib- with vehicle-treated cells, ${ }^{*} P<0.01$. (C) $C B$ activity was measured at $12 \mathrm{~h}$ after $20 \mu \mathrm{m}$ sunitinib, $10 \mu \mathrm{m}$ CA074Me or vehicle treatment by using the fluorogenic peptide Z-Arg-Arg-AMC and the SpectraMax Gemini XPS microplate reader. Data shown are the mean \pm s.d. of three independent experiments. Densitometric analysis was performed by comparing

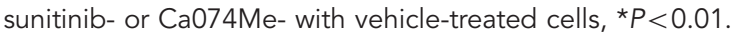
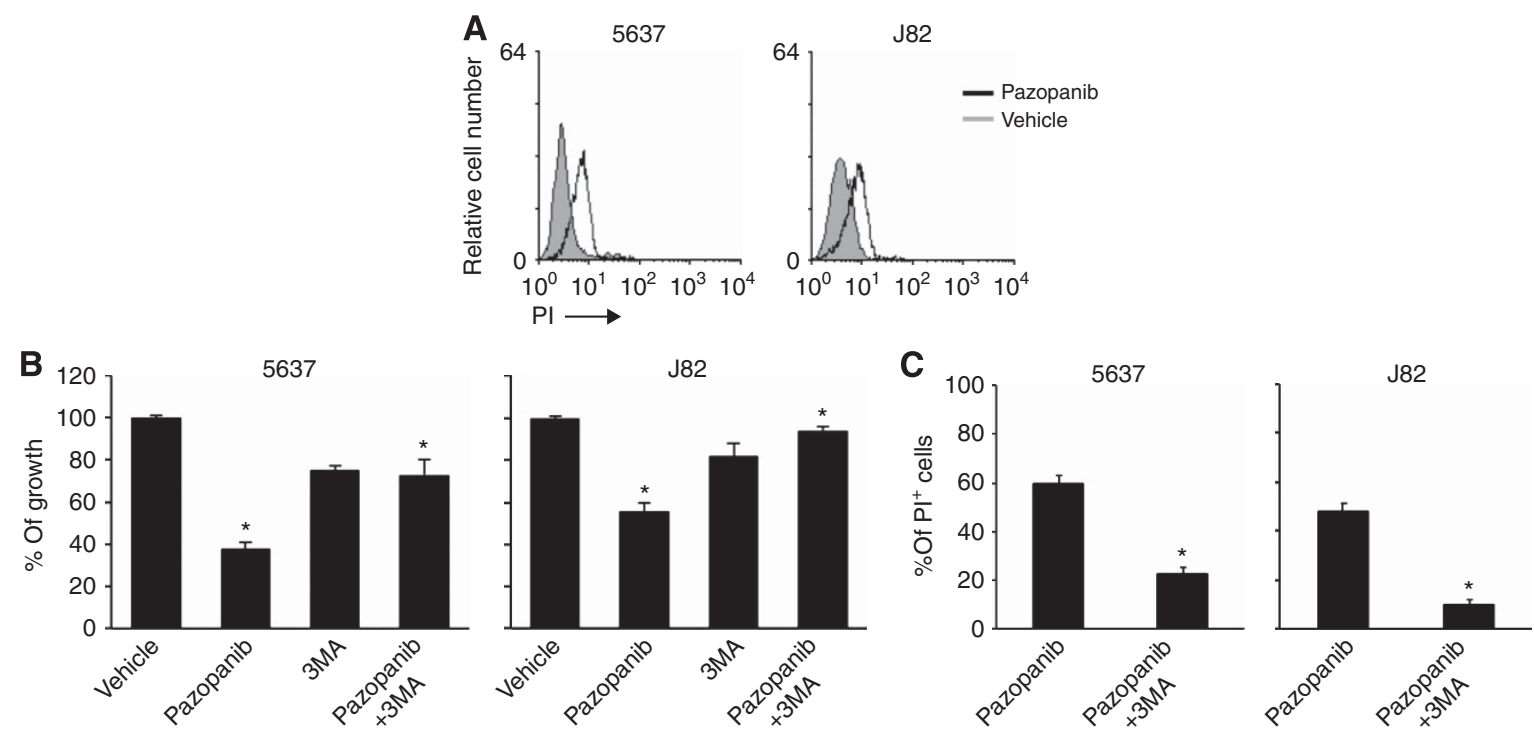

Figure 6. Pazopanib induces autophagic cell death of BC cells. (A) 5637 and J82 cells treated with $20 \mu \mathrm{M}$ pazopanib for $48 \mathrm{~h}$ were stained with $\mathrm{PI}$ and analysed by FACS. Data shown represent one out of three separate experiments. (B) Cell growth of 5637 and J82 cells treated with vehicle, $20 \mu \mathrm{M}$ pazopanib alone or in combination with $2.5 \mathrm{~mm}$ of $3 \mathrm{MA}$ was evaluated by MTT assay at $48 \mathrm{~h}$ after treatment. Data shown are the mean $\pm \mathrm{s} . \mathrm{d}$. of three independent experiments. Statistical analysis was performed by comparing pazopanib- with vehicle-treated cells and pazopanib plus $3 \mathrm{MA}$ - with pazopanib-treated cells, ${ }^{*} P<0.01$. (C) 5637 and J82 cells treated with $20 \mu \mathrm{M}$ pazopanib for $48 \mathrm{~h}$ alone or in combination with $2.5 \mathrm{~mm}$ $3 \mathrm{MA}$ were stained with PI and analysed by FACS. Data shown represent the percentage of $\mathrm{PI}^{+}$cells and are the mean $\pm \mathrm{s}$.d. of three independent experiments. Statistical analysis was performed by comparing pazopanib plus 3MA- with pazopanib-treated cells, ${ }^{\star} P<0.01$.

downregulation of the BCL2/adenovirus E1B $19 \mathrm{kDa}$ interacting protein 3 (BNIP3), heat-shock protein $90 \mathrm{kDa}$ alpha, class $\mathrm{A}$ member 1 (HSP90AA1), tumour necrosis factor a (TNF) and tumour protein p73 (TP73) genes was observed in 5637 cells (Table 1). In addition, the increase of the arylsulfatase A (ARSA), GAA, transglutaminase 2, C polypeptide (TG2) and Unc-51-like 


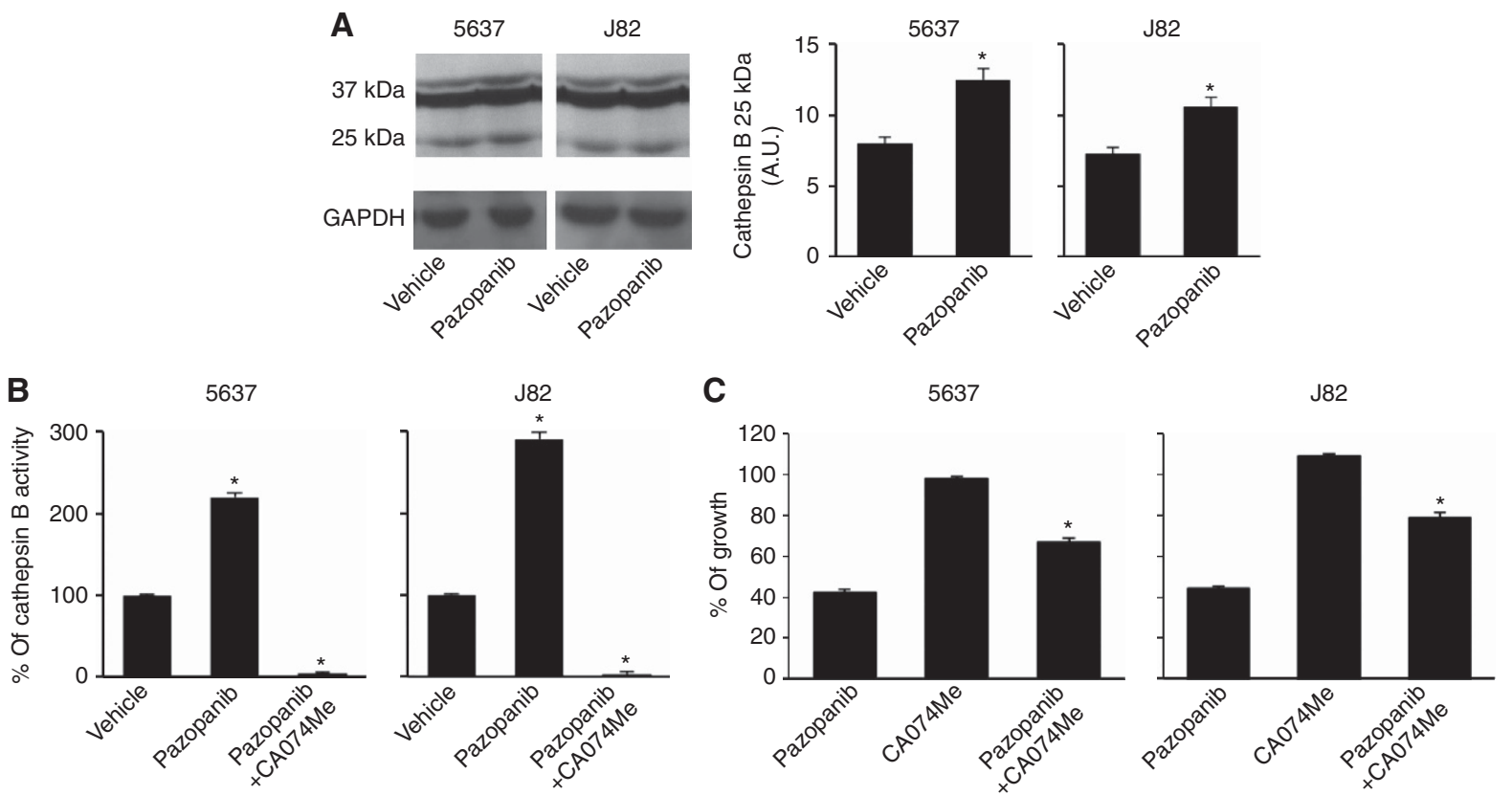

Figure 7. Pazopanib increases CB activation and enzymatic activity in BC cells. (A) Lysates from 5637 and J82 cell lines, treated with $20 \mu \mathrm{M}$ pazopanib or vehicle for $24 \mathrm{~h}$, were separated on $12 \%$ SDS-PAGE and probed with anti-CB or anti-GAPDH Abs, respectively. Densitometric analysis, expressed as the mean \pm s.d., was performed by comparing pazopanib- with vehicle-treated cells, ${ }^{\star} P<0.01$. (B) CB activity was measured at $12 \mathrm{~h}$ after $20 \mu \mathrm{m}$ pazopanib alone or in combination with $2.5 \mu \mathrm{M}$ CA074Me or vehicle by using the fluorogenic peptide Z-Arg-Arg-AMC. The fluorescence of the hydrolysed 7-amino-4-methyl-coumarin was detected on a SpectraMax Gemini XPS microplate reader. The CB contribution to the proteolysis was evaluated by using the specific inhibitor CA074Me. Data shown are the mean \pm s.d. of three independent experiments. Densitometric analysis, expressed as the mean \pm s.d., was performed by comparing pazopanib- with vehicle-treated cells and pazopanib plus CA074Me- with pazopanib-treated cells, ${ }^{*} P<0.01$. (C) Cell growth of 5637 and J82 cells treated with $20 \mu \mathrm{M}$ pazopanib alone or in combination with $2.5 \mu \mathrm{M}$ CA074Me was evaluated by MTT assay at $48 \mathrm{~h}$ after treatment. Data shown are the mean \pm s.d. of three independent experiments. Statistical analysis was performed by comparing pazopanib plus CA074Me- with pazopanib-treated cells, ${ }^{\star} P<0.01$.

Table 1. Changes in gene expression induced by $20 \mu \mathrm{M}$ pazopanib in 5637 and J82 BC cells

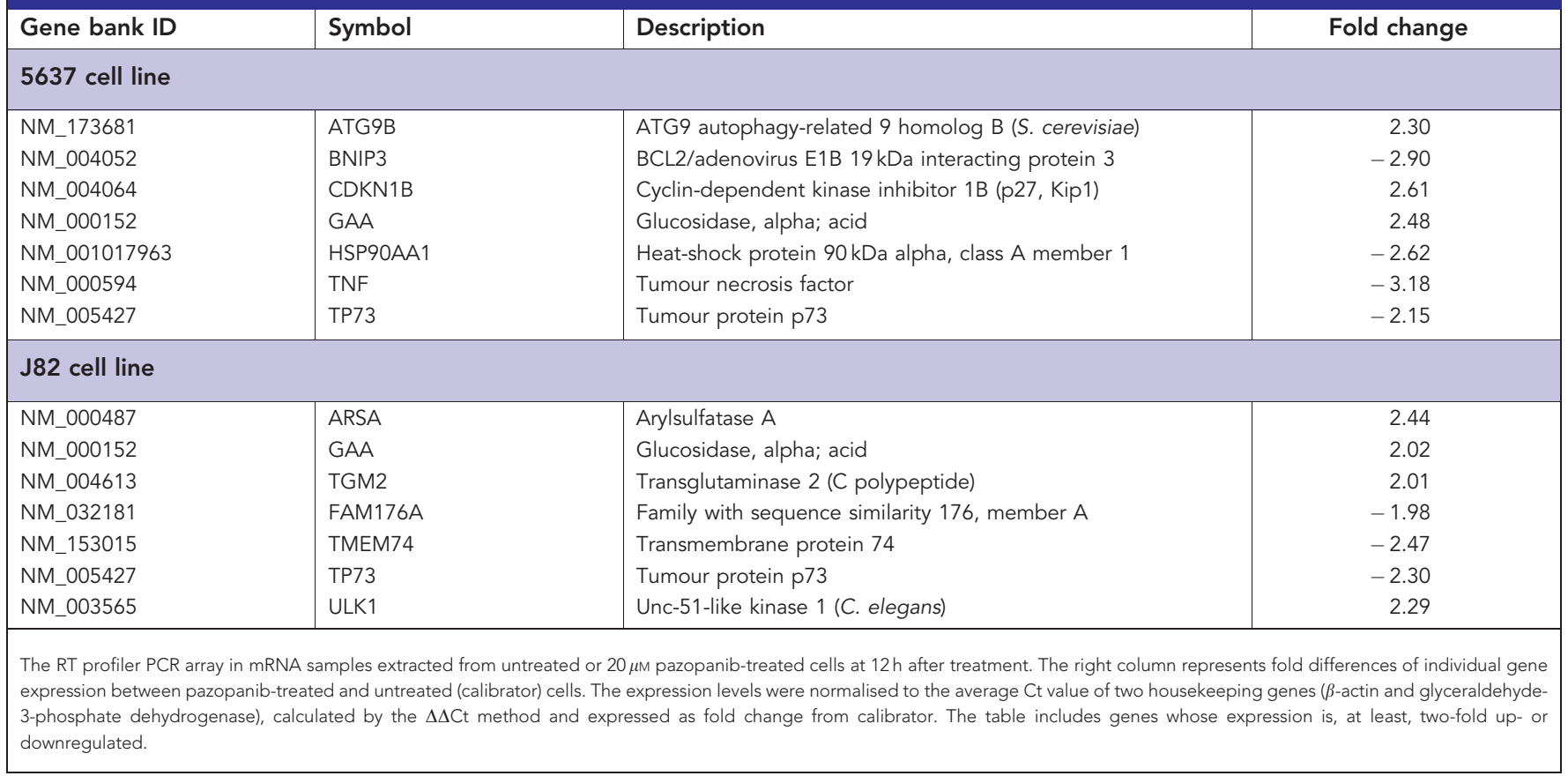


kinase 1 (ULK1) genes and the decrease of the transmembrane protein 74 (TMEM74) and tumour protein p73 (TP73) gene expression levels were shown in J82 cells (Table 1).

\section{DISCUSSION}

Sunitinib and pazopanib act on cell surface receptors known to be aberrantly activated in cancers. They have been shown to reduce cell proliferation and angiogenesis and induce apoptosis in human cancer cell lines and xenografts, but the molecular mechanisms that undergo direct anti-tumour effects have been poorly addressed so far.

Autophagy is the main machinery for the sequestration of cellular constituents into lysosomes. It begins with the elongation of the isolation membrane (phagophore) that enwraps cytoplasmic constituents such as organelles until its edges fuse with each other to form a double-membrane structure called autophagosome, which fuses with the lysosome where the sequestred cytoplasmic components are completely degradated by the lysosomal hydrolases (Yang and Kliosky, 2010; Tanida, 2011).

In this study, we found that both sunitinib and pazopanib are able to activate the autophagic process, as evaluated by the conversion of LC3-I to LC3-II, the membrane-bound lipidated form of LC3, with an increase of LC3-II/LC3-I ratio. However, in sunitinib-treated BC cells, despite the increase of LC3-II, an accumulation of the sequestosome-1/p62 protein, probably due to defective lysosomal degradation or AVOs and autophagolysosome formation, was observed. Thus, abrogation of autophagy disruption, 'incomplete autophagy', resulted in p62 accumulation. By contrast, pazopanib induced autophagy, as evaluated by the increase of LC3-II protein, AVO formation, p62 degradation and autophagic flux. In addition, pazopanib increased pERK1/2 phosphorylation in BC cells, and a specific MEK1 inhibitor, PD98059, reduced the pazopanib-induced autophagy. Similarly in different experimental models, pharmacological blockade of ERK phosphorylation with the use of U0126 or PD98059 inhibitors or ERK knock-down, by downregulating the LC3-II levels, reduced the autophagic process (Sivapravad and Basu, 2008; Oh and Lim, 2009).

Incomplete autophagy has been found to trigger cell death (Schmukler et al, 2012), and lysosomes are important players in triggering mitochondrial-dependent apoptosis, mitochondrialindependent necrosis and autophagy (Kroemer and Jäättelä, 2005; Kirkegaard and Jäättelä, 2009; Groth-Pedersen and Jäättelä, 2010).

In this regard, sunitinib accumulated in lysosomes of BC cells, thereby increasing the lysosome $\mathrm{pH}$, impaired lysosomial $\mathrm{CB}$ activity (Mach et al, 1994; Turk and Turk, 2009). In addition, sunitinib-induced necrosis of BC cells was completely inhibited by the lysosomial inhibitors, bafilomycin A1 or CQ, which reduce lysosome acidification (Yoshimori et al, 1991). Lysosomotrophic drugs are also efficiently trapped in mitochondria and their concentration induces rapid loss of $\Delta \Psi_{\mathrm{m}}$, which promotes apoptotic or necrotic cell death (Marceau et al, 2012). Moreover, $\mathrm{CB}$ has been shown to cause substantial increase in ROS generation by mitochondria (Zhao et al, 2003). Here, we showed that sunitinib-induced inhibition of $\mathrm{CB}$ functional activity abrogates ROS generation and mitochondrial depolarisation, indicating that this agent is only sequestrated via a V-ATPase mechanism inside lysosomes.

Previous reports have shown the ability of anticancer drugs to induce autophagic death of tumour cells (Notte et al, 2011). Herein we found that pazopanib induces autophagic death of BC cells, which is markedly reverted by the autophagic inhibitor, 3-MA.
$\mathrm{CB}$, primarily implicated in the degradation of lysosomal proteins, is also shown to be involved in cell death (Willingham et al, 2007) and autophagic vesicle trafficking (Ha et al, 2009). In this regard, our findings show that the autophagic cell death of $\mathrm{BC}$ cells induced by pazopanib is associated with increased CB activity and is markedly abrogated by CA074Me.

Finally, we evaluated the molecular mechanism induced in BC cells by pazopanib at $12 \mathrm{~h}$ after treatment. Comparative gene expression analysis in 5637 and J82 cell lines indicated that pazopanib induced upregulation of GAA and downregulation of p73 mRNA.

GAA is involved in the breakdown of glycogen from glucose in the acid milieu of lysosomes (Rosenfeld, 1975), and autophagy represent a presumed mechanism of glycogen trafficking to lysosomes (Raben et al, 2005; Kotoulas et al, 2006). With regard to $\mathrm{p} 73$ belonging to the p53-suppressor gene family (Rosenbluth and Pietenpol, 2009), downregulation of p73 is in accordance with a dualistic role of 73 protein in both inhibition and activation of autophagy.

In 5637 cells, pazopanib increased the expression of ATG9 involved in membrane trafficking, autophagosome formation (Noda et al, 2000; Xie and Kliosky, 2007) and fusion with lysosomes (Kraft et al, 2012), and ULK1 which regulates the initial events of autophagosome formation (Young et al, 2006). Similarly to the autophagy of biliary epithelial cells (Sasaki et al, 2012), an increase of CDKN1B, the inhibitor of p21/p27, was observed in pazopanib-treated 5637 cells. Finally, gene profile of J82 cells shows upregulation of the lysosomial ARSA and TG2 genes involved in autophagolysosome maturation (D'Eletto et al, 2009).

Bladder Cancer is sensitive to chemotherapy and shows response rates of $45-50 \%$ in the first-line setting. Although, chemotherapy confers survival vantage, it is rarely curative, and relapse after firstline therapy is commonly known during the course of treatment. Thus, due to the lack of durable responses and severe side-effects, it is far from being satisfactory. Therefore target therapy with novel drugs directed at specific molecular pathways might open new avenues to improve patient outcome. Currently, TKIs seem to be the target agents that have been investigated extensively in second-line TCC, although they have not achieved the same clinical benefit in this disease as seen in other common epithelial cancers (Gerullis et al, 2012). Many of this new targeted agents have been investigated as single agents in phase II clinical trials without convincing oncological outcomes. In addition, the combination of targeted agents with chemotherapeutic drugs have not been shown to be an appropriate alternative. Although some positive preclinical studies with pazopanib in combination with docetaxel have been reported (Li et al, 2011), no satisfactory results in terms of clinical benefit have been obtained by the use of sunitinib or pazopanib in combination with cisplatin, paclitaxel or vinflunine with respect to their use as single agent in second-line approaches (Sonpavde et al, 2009; Bellmunt et al, 2011; Gerullis et al, 2013). Thus, the introduction of different TKIs in combination or sequential therapeutic strategies, together with patient selection criteria, and the development of prognostic biomarkers will be of importance in the future (Zhu et al, 2012).

Although sunitinib and pazopanib are both TKIs and are often used interchangeably in the clinical setting, they do not have identical targets and binding specificities. Furthermore, they differ with respect to the side-effects profile and with respect to the profound differences in cell death mechanisms against BC cells (lysosomial necrosis for sunitinib vs autophagic cell death for pazopanib). Collectively, we think that this plethora of data may provide the rationale for the sequential use of TKIs in the management of BCs. Thus, at present, it will be important to identify the optimal sequential effective order to administer TKIs, to maximise the benefit and minimise the toxicity. 
In conclusion, the understanding of the autophagic processes induced by different TKIs may allow clinicians to exploit this strategy as a new potential target for anticancer therapy.

\section{REFERENCES}

Bellmunt J, González-Larriba JL, Prior C, Maroto P, Carles J, Castellano D, Mellado B, Gallardo E, Perez-Gracia JL, Aguilar G, Villanueva X, Albanell J, Calvo A (2011) Phase II study of sunitinib as first-line treatment of urothelial cancer patients ineligible to receive cisplatin-based chemotherapy: baseline interleukin-8 and tumor contrast enhancement as potential predictive factors of activity. Ann Oncol 22: 2646-2653.

Chan ES, Patel AR, Hansel DE, Larchian WA, Heston WD (2012) Sunitinib malate provides activity against murine bladder tumor growth and invasion in a preclinical orthotopic model. Urology 80(736): e1-e5.

D'Eletto M, Farrace MG, Falasca L, Reali V, Oliviero S, Melino G, Griffin M, Fimia GM, Piacentini M (2009) Transglutaminase 2 is involved in autophagosome maturation. Autophagy 5: 1145-1154.

Demetri GD, van Oosterom AT, Garrett CR, Blackstein ME, Shah MH, Verweij J, McArthur G, Judson IR, Heinrich MC, Morgan JA, Desai J, Fletcher CD, George S, Bello CL, Huang X, Baum CM, Casali PG (2006) Efficacy and safety of sunitinib in patients with advanced gastrointestinal stromal tumor after failure of imatinib: a randomised controlled trial. Lancet 368: 1329-1381.

Faivre S, Demetri G, Sargent W, Raymond E (2007) Molecular basis for sunitinib efficacy and future clinical development. Nat Rev Drug Discov 6: $734-745$.

Ferri KF, Kroemer G (2001) Organelle-specific initiation of cell death pathways. Nat Cell Biol 3: E255-E263.

Funk RS, Krise JP (2012) Cic amphiphilic drug cause a marked expansion of apparent lysosomial volume: implications for an intracellular distributionbased drug interaction. Mol Pharm 9: 1384-1395.

Gallagher DJ, Milowsky MI, Gerst SR, Ishill N, Riches J, Regazzi A, Boyle MG, Trout A, Flaherty AM, Bajorin DF (2010) Phase II study of sunitinib in patients with metastatic urothelial cancer. J Clin Oncol 28: 1373-1379.

Gerullis H, Otto T, Ecke TH (2012) Target agents in second-line bladder cancer therapy. Anticancer Drugs 23: 1003-1015.

Gerullis H, Eimer C, Ecke TH, Georgas E, Arndt C, Otto T (2013) Combined treatment with pazopanib and vinflunine in patients with advanced urothelial carcinoma refractory after first-line therapy. Anticancer Drugs 24: $422-425$.

Gotink KJ, Broxterman HJ, Labots M, de Haas RR, Dekker H, Honeywell RJ, Rudek MA, Beerepoot LV, Musters RJ, Jansen G, Griffioen AW, Assaraf YG, Pili R, Peters GJ, Verheul HM (2011) Lysosomal sequestration of sunitinib: a novel mechanism of drug resistance. Clin Cancer Res 17: 7337-7346.

Gozuacik D, Kimchi A (2004) Autophagy as cell death and tumor suppressor mechanism. Oncogene 23: 2891-2906.

Groth-Pedersen L, Jäättelä M (2010) Combating apoptosis and multidrug resistant cancers by targeting lysosomes. Cancer Lett 332: 265-274.

Ha SD, Ham B, Mogridge J, Saftig P, Lin S, Kim O (2009) Cathepsin $\mathrm{B}$-mediated autophagy flux facilitates the anthrax toxin receptor2 -mediated delivery of anthrax lethal factor in the cytoplasm. J Biol Chem 285: 2120-2129.

Jaakkola PM, Pursiheimo J-P (2009) p62 degradation by autophagy: another way for cancer to survive under hypoxia. Autophagy 5: 410-412.

Jemal A, Siegel R, Xu J, Ward E (2010) Cancer Statistics, 2010. CA Cancer J Clin 60: 277-300.

Johansen T, Lamark T (2011) Selective autophagy mediated by autophagic adapter proteins. Autophagy 7: 279-296.

Kaufmann AM, Krise JP (2007) Lysosomal sequestration of amine-containing drugs: analysis and therapeutic implications. J Pharm Sci 96: 729-746.

Kirkegaard T, Jäättelä M (2009) Lysosomal involvement in cell death and cancer. Biochim Biophys Acta 1793: 746-754.

Komatsu M, Waguri S, Koike M, Sou YS, Ueno T, Hara T, Mizushima N, Iwata J, Ezaki J, Murata S, Hamazaki J, Nishito Y, Iemura S, Natsume T, Yanagawa T, Uwayama J, Warabi E, Yoshida H, Ishii T, Kobayashi A, Yamamoto M, Yue Z, Uchiyama Y, Kominami E, Tanaka K (2007) Homeostatic levels of p62 control cytoplasmic inclusion body formation in autophagy-deficient mice. Cell 131: 1149-1163.

Kotoulas OB, Kalamidas SA, Kondomerkos DJ (2006) Glycogen autophagy in glucose homeostasis. Pathol Res Pract 202: 631-638.
Kraft C, Kijanska M, Kalle E, Lee SS, Semplicio G, Stoffel I, Brezovich A, Verma M, Hansmann I, Ammerer G, Hojmann K, Tooze S, Peter M (2012) Binding of the Atg1/ULK1 kinase to the ubiquitin-like protein Atg8 regulates autophagy. EMBO J 31: 3691-3703.

Kroemer G, Jäättelä M (2005) Lysosomes and autophagy in cell death control. Nat Rev Cancer 5: 886-897.

Li Y, Yang X, Su LJ, Flaig TW (2011) Pazopanib synergizes with docetaxel in the treatment of bladder cancer cells. Urology 78(233): e7-13.

Mach L, Mort JS, Glossl J (1994) Maturation of human procathepsin B. Proenzyme activation and proteolytic processing of the precursor to the mature proteinase, in vitro, are primarily unimolecular processes. J Biol Chem 269: 13030-13035.

Marceau F, Bawolak MT, Lodge R, Bouthillier J, Gagné-Henley A, Gaudreault RC, Morissette G (2012) Cation trapping by cellular acidic compartments: beyond the concept of lysosomotropic drugs. Toxicol Appl Pharmacol 259: $1-12$.

Mizushima M, Yoshimori T, Levine B (2010) Methods in mammalian autophagy research. Cell 140: 313-326.

Motzer RJ, Hutson TE, Tomczak P, Michaelson MD, Bukowski RM, Rixe O, Oudard S, Negrier S, Szczylik C, Kim ST, Chen I, Bycott PW, Baum CM, Figlin RA (2007) Sunitinib versus interferon alfa in metastatic renal-cell carcinoma. N Engl J Med 356: 115-124.

Nadanaciva S, Lu S, Gebhard DF, Jessen BA, Pennie WD, Will Y (2011) A high content screening assay for identifying lysosomotropic compounds. Toxicol in vitro 25: 715-723.

Necchi A, Mariani L, Zaffaroni N, Schwartz LH, Giannatempo P, Crippa F, Morosi C, Lanocita R, Sava T, Ortega C, Messina C, Sacco C, Pennati M, Daidone MG, Nicolai N, Braud De, Gianni AM, Salvioni R (2012) Pazopanib in advanced and platinum-resistant urothelial cancer: an openlabel, single group, phase 2 trial. Lancet Oncol 13: 810-816.

Noda T, Kim J, Huang WP, Baba M, Tokunaga C, Ohsumi Y, Klionsky DJ (2000) Apg9p/Cvt7 is an integral membrane protein required for transport vesicle formation in the Cvt and autophagy pathways. J Cell Biol 148: $465-480$.

Notte A, Leclere L, Michiels C (2011) Autophagy as a mediator of chemotherapy-induced cell death in cancer. Biochem Pharmacol 82: $427-434$.

O'Farrell AM, Abrams TJ, Yuen HA, Ngai TJ, Louie SG, Yee KW, Wong LM, Hong W, Lee LB, Town A, Smolich BD, Manning WC, Murray LJ, Heinrich MC, Cherrington JM (2003) SU11248 is a novel FLT3 tyrosine kinase inhibitor with potent activity in vitro and in vivo. Blood 101: 3597-3605.

Oh SH, Lim SC (2009) Endoplasmic reticulum stress-mediated autophagy/ apoptosis induced by capsaicin (8-methyl-N-vanillyl-6-nonenamide) and dihydrocapsaicin is regulated by the extent of c-Jun NH2-terminal kinase/ extracellular signal-regulated kinase activation in WI38 lung epithelial fibroblast cells. J Pharmacol Exp Ther 329: 112-122.

Puissant A, Colosetti P, Robert G, Cassuto JP, Raynaud S, Auberger P (2010) Cathepsin B release after imitanib-mediated lysosomal membrane permeabilization triggers BCR-ABL cleavage and elimination of chronic myelogenous leukemia cells. Leukemia 24: 115-124.

Pursiheimo JP, Rantanen K, Heikkinen PT, Johansen T, Jaakkola PM (2009) Hypoxia-activated autophagy accelerates degradation of SQSTM1/p62. Oncogene 28: 334-344.

Raben N, Fukuda T, Gilbert AL, de Jong D, Thurberg BL, Mattaliano RJ, Meikle P, Hopwood JJ, Nagashima K, Nagaraju Ka, Plotz PH (2005) Replacing acid alpha-glucosidase in Pompe disease: recombinant and transgenic enzymes are equipotent, but neither completely clears glycogen from type II muscle fibers. Mol Ther 11: 48-56.

Rodriguez A, Durán A, Selloum M, Champy MF, Diez-Guerra FJ, Flores JM, Serrano M, Auwerx J, Diaz-Meco MT, Moscat J (2006) Mature-onset obesity and insulin-resistance in mice deficient in the signaling adapter p62. Cell Metab 3: 211-222.

Rosenbluth JM, Pietenpol JA (2009) mTOR regulates autophagy-associated genes downstream of p73. Autophagy 5: 114-116.

Rosenfeld EL (1975) Alpha-glucosidases (gamma-amylases) in human and animal organisms. Pathol Biol (Paris) 23: 71-84.

Sasaki M, Miyakoshi M, Sato Y, Nakanuma Y (2012) A possible involvement of p62/sequestosome-1 in the process of biliary epithelial autophagy and senescence in primary biliary cirrhosis. Liver Int 32: 487-499.

Schmukler E, Shai B, Ehrlich M, Pinkas-Kramarski R (2012) Neuregulin promotes imcomplete autophagy of prostate cancer cells that is independent of mTOR pathway inhibition. PLoS One 7: e36828. 
Schueneman AJ, Himmelfarb E, Geng L, Tan J, Donnelly E, Mendel D, McMahon G, Hallahan DE (2003) SU11248 maintenance therapy prevents tumor regrowth after fractionated irradiation of murine tumor models. Cancer Res 63: 4009-4016.

Sivaprasad U, Basu A (2008) Inhibition of ERK attenuates autophagy and potentiates tumour necrosis factor-alpha-induced cell death in MCF-7 cells. J Cell Mol Med 12: 1265-1271.

Sonpavde G, Jian W, Liu H, Wu MF, Shen SS, Lerner SP (2009) Sunitinib malate is active against human urothelial carcinoma and enhances the activity of cisplatin in a preclinical model. Urol Oncol 27: 391-399.

Sternberg CN, Davis ID, Mardiak J, Szczylik C, Lee E, Wagstaff J, Barrios CH, Salman P, Gladkov OA, Kavina A, Zarbá JJ, Chen M, McCann L, Pandite L, Roychowdhury DF, Hawkins RE (2010) Pazopanib in locally advanced or metastatic renal cell carcinoma: results of a randomized phase III trial. J Clin Oncol 28: 1061-1068.

Takeuchi A, Eto M, Shiota M, Tatsugami K, Yokomizo A, Kuroiwa K, Itsumi M, Naito S (2012) Sunitinib enhances antitumor effects against chemotherapy-resistant bladder cancer through suppression of ERK1/2 phosphorylation. Int J Oncol 40: 1691-1696.

Tanida I (2011) Autophagosome formation and molecular mechanism of autophagy. Antioxid Redox Signal 14: 2201-2214.

Tchoupe JR, Moreau T, Gauthier F, Bieth JG (1991) Photometric or fluorometric assay of cathepsin B, L and $\mathrm{H}$ and papain using substrates with an aminotrifluoromethylcoumarin leaving group. Biochim Biophys Acta 1076: 149-151.

Turk B, Turk V (2009) Lysosome as "suicide bags" in cell death: myth or reality? J Biol Chem 284: 21783-21787.

van der Graaf WT, Blay JY, Chawla SP, Kim DW, Bui-Nguyen B, Casali PG, Schöffski P, Aglietta M, Staddon AP, Beppu Y, Le Cesne A, Gelderblom H, Judson IR, Araki N, Ouali M, Marreaud S, Hodge R, Dewji MR, Coens C, Demetri GD, Fletcher CD, Dei Tos AP, Hohenberger P, Thomson DB, Powel A, Friedlander M, Kotasek D, Harrup R, Gil T, Mazzeo F, Gennigens C, Krarup-Hansen A, Penel N, Rios M, Piperno-Neumann S, Duffaud F, Collard O, Egerer G, Wendtner CM, Bauer S, Gruenwald V, Steffen B, Folprecht G, Reichardt P, Siena S, Ferraresi V, Apice G, Comandone A, Roila F, Yokoyama R, Isu K, Sugiura H, Matsumine A, Ueda T, Ishii T, Ozaki T, Lee SH, Yun T, Lee KH, Rha SY, Ahn JH, Lee J, Martin Broto J, Casado Herraez A, Eriksson M, Engstroem K, Cavalli-Bjorkman N, Erlanson M, Wall N, Kerst J, Sleijfer S, Marples M, Woll P, Leahy MG, White JD, Hennig I, Conry R, Skubitz K, Fruehauf J,
Singh D (2012) Pazopanib for metastatic soft-tissue sarcoma (PALETTE): a randomised, double-blind, placebo-controlled phase 3 trial. Lancet 379: 1879-1886.

Willingham SB, Bergstralh DT, O'Connor W, Morrison AC, Taxman DJ, Duncan JA, Barnoy S, Venkatesan MM, Flavell RA, Deshmukh M, Hoffman HM, Ting JP (2007) Microbial pathogen-induced necrotic cell death mediated by the inflammasome components CIAS1/cryopyrin/ NLRP3 and ASC. Cell Host Microbe 2: 147-159.

Wu CL, Ping SY, Yu CP, Yu DS (2012) Tyrosine kinase receptor inhibitortargeted combined chemotherapy for metastatic bladder cancer. Kaohsiung J Med Sci 28: 194-203.

Xie Z, Kliosky DJ (2007) Autophagosome formation: core machinery and adaptations. Nat Cell Biol 9: 1102-1109.

Yang Z, Kliosky DJ (2010) Eaten alive: a history of macroautophagy. Nat Cell Biol 12: 814-822.

Yoon CY, Lee JS, Kim BS, Jeong SJ, Hong SK, Byun SS, Lee SE (2011) Sunitinib malate synergistically potentiates anti-tumor effect of gemcitabine in human bladder cancer cells. Korean J Urol 52: 55-63.

Yoshimori T, Yamamoto A, Moriyama Y, Futai M, Tashiro Y (1991) Bafilomycin A1, a specific inhibitor of vacuolar-type $\mathrm{H}(+)$-ATPase, inhibits acidification and protein degradation in lysosomes of cultured cells. J Biol Chem 266: 17707-17712.

Young AR, Chan EY, Hu XW, Köchl R, Crawshaw SG, High S, Hailey DW, Lippincott-Schwartz J, Tooze SA (2006) Starvation and ULK1-dependent cycling of mammalian Atg9 between the TGN and endosome. J Cell Sci 119: 3888-3900.

Zhao M, Antunes F, Eaton JW, Brunk UT (2003) Lysosomal enzymes promote mitochondrial oxidant production, cytochrome $\mathrm{c}$ release and apoptosis. Eur J Biochem 270: 3778-3786.

Zhu Z, Shen Z, Xu C (2012) Targeted therapy for advanced urothelial cancer of the bladder: where do we stand? Anticancer Agents Med Chem 12: 1081-1087.

This work is published under the standard license to publish agreement. After 12 months the work will become freely available and the license terms will switch to a Creative Commons AttributionNonCommercial-Share Alike 3.0 Unported License.

Supplementary Information accompanies this paper on British Journal of Cancer website (http://www.nature.com/bjc) 